\title{
Delignification of Rice Straw with Ligninase from Novel Penicillium sp. strain apw-tt2 for Biopulping
}

\author{
Asri Peni Wulandari, Tika Triyana, and Poniah Andayaningsih
}

\begin{abstract}
Study of biodelignification of rice straw was investigated by using a fungus isolated from indigenous the straw. Identification of the fungus was characterized by $18 \mathrm{~s}$ rRNA sequencing and included in the new species of Penicillium sp. strain apw-tt2. Ligninase production and cell growth was observed in incubation condition of Submerged Fermentation (SmF). Optimizations of the enzyme production condition were carried out by altering $\mathrm{pH}$ and temperature of the incubation medium. The results showed that the optimum conditions for biopulping are at $40^{\circ} \mathrm{C}$ and $\mathrm{pH} 5$. High ligninase production was observed at Day 4 with activity $571 \mathrm{U} / \mathrm{ml}$ with degraded lignin $66.3 \%$. The quality of pulp showed that the new species is very effective in delignifying rice straw for pulping.
\end{abstract}

Index Terms-Penicillium sp., delignification, 18s rRNA, ligninase, biopulping

\section{INTRODUCTION}

Indonesia as an agricultural country producing rice straw with a very large amount, however the straw is still regarded as a waste which will ultimately be burned without further utilized.

Delignification is a process separation of lignin from cellulose. Removing lignin by chemical method still widely used mainly as a method of pulping industry and this process is very important in the industry of pulp and paper. Biopulping needed in the industry since delignification process can be environmentally friendly and reduce the cost of production.

Process of making pulp (cellulose fiber) are biologically using ligninolytic microorganism. The most efficient fungi for lignin degradation are included as white rot-fungi which produce ligninase that capable to modify lignin from organic material such as wood, bamboo, or straw. The enzymatic system of ligninase comprising of laccase and peroksidase which has been consider as a useful enzymes for the improvement of biotecnology process for biopulping and biobleaching.

Most researches showed that white-rot fungi as effective lignin decomposer such as Phanerochaeta chrysosporium[1], Agaricus bisporus [2], Pleurotus ostreatus [3], Bjerkandera adusta [4], Curvularia lanata [5], Pleurotus sajor-caju [6],[7]. The soft rot fungi (Ascomycetes) capable to decompose lignin as well. Aspergillus fumigatus, A.

Manuscript received October 15, 2012; revised November 20, 2012. This work was supported in part by The Ministry of Education National, Indonesia.

Asri Peni Wulandari is with the Universitas Padjadjaran, Indonesia (e-mail: asri.peni@unpad.ac.id).

Tika Triyana and Poniah Andayaningsih are with the Department of Biology, Universitas Padjadjaran. japonicas, A. niger, A. terreus [8], Penicillium sp. [9] and $P$. chrysosporium [10] have the ability to degrade aromatic compounds such as lignin.

Quality of pulp can be seen from the ratio of lignin and cellulose. Pulping process produces pulp of good quality when producing low levels of degradation of cellulose in the presence of high level lignin dissolution. Comparison between biopulping and chemical pulping processes based on the percentage of reduction in lignin content shows the results of each are $44.05 \%$ and $56.41 \%$. Several studies have shown that biodegradation of lignin by fungi ligninolytic reduced lignin content by $20-30 \%$ within 60 days, when delignification performed on sawdust reduced the lignin $19 \%$ while the cellulose by $6 \%$ for 60 days [11].

For the purpose of producing ligninase, ligninolytic fungi will have a higher activity when incubation condition using submerged fermentation technique or Submerged fermentation (SMF) compared to solid fermentation or Solid State Fermentation (SSF) [12].

The aim of the study was to investigated the potency of straw-indigenous Penicillium sp. strain apw-tt2 capable of producing ligninase for biopulping process.

\section{MATERIAL AND METHODS}

\section{A. Rice Straw}

Rice straw used in this study were collected from Arboretum, Universitas Padjadjaran, West Java, Indonesia.

Isolate Penicillium sp. strain apw-tt2 is a collection of Laboratory of Microbiology, Department of Biology, Padjadjaran University, Indonesia.

\section{B. Enzyme Preparation and Assay Enzyme}

Commercially available Kraft lignin (Sigma) was used throughout this study.

Modification of enzyme preparation and assay enzyme were carried out according to assay ligninase [2], [7]. Crude enzyme extract ligninase was taken $(1 \mathrm{ml})$, centrifuged for 20 minutes at $2000 \mathrm{rpm}$. The supernatant was taken $0.4 \mathrm{~mL}$ then mixed with $0.5 \mathrm{~mL}$ of $100 \mathrm{mM}$ acetate buffer $\mathrm{pH} 5$ and $0.1 \mathrm{~mL}$ of lignin [2]. This mixture was fed into the cuvette and incubated for $10 \mathrm{~min}$ at $30^{\circ} \mathrm{C}$. The absorbance of the sample was measured at a wavelength of $383 \mathrm{~nm}$. Observations were made every 24 hours for 10 days. Each sample was tested twice (duplicate). One unit of activity was defined as the ligninase which released for $1 \mu \mathrm{mol}$ product per min or increase in absorbance at $383 \mathrm{~nm}$ per min per ml assay mixture at $\mathrm{pH} 5$. 


\section{Identification of Strain}

Based on morphological structure, the fungus characterized as genus Penicillium. Determination of species identification was done by analysis $18 \mathrm{~s}$ rRNA. The liquid samples contain of the fungus were centrifuged, the DNA (pellet) was taken and added lyticase. DNA was isolated with the High Pure mushroom Purification Kit (Roche). The total DNA concentration was measured using Eppendorf BioPhotometer plus UV/Vis, then amplified in vitro by PCR was set by giving the program for first denaturation at $94^{\circ} \mathrm{C}$ for $2 \mathrm{~min}$, 2nd denaturation at $94^{\circ} \mathrm{C}$ for $1 \mathrm{~min}$, annealing $1 \mathrm{~min}$, and extension $72^{\circ} \mathrm{C}$ for $1 \mathrm{~min}$ and $10 \mathrm{~min}$. 18s rRNA amplicon DNA were analyzed in PT Genetic Science (Singapura). Consensus sequences (about $1165 \mathrm{bp}$ ) from each OTU (Operational Taxonomic Unit) were compared with other 18s rRNA genes in Gen Bank (NCBI).

Consensus sequences (about $1165 \mathrm{bp}$ ) from each OTU (Operational Taxonomic Unit) were compared to other 18s rRNA genes in Gen Bank (NCBI) using BLAST search from NCBI and aligned to closely related sequences identified from the BLAST search. The phylogenetic tree was inferred using the Clustal method. The ready sequenced data for related taxa were available at (http://blast.ncbi.nlm.nih.gov/Blast.cgi).

\section{Delignification of Rice Straw}

Delignification of the straw was carried out in 250-ml Erlenmeyer flask containing $1 \mathrm{~g}$ of the straw and $10 \mathrm{ml}$ of cell-free supernatant from 3 day old of culture. Flasks were incubated at the $\mathrm{pH} 5$ and temperature $40^{\circ} \mathrm{C}$.

Control contained sterile medium instead of culture supernantant.

\section{E. Dependence of Enzyme Activity on Temperature and} pH Optimization

To examine the temperature optimum of the reaction ligninase, the enzyme reaction was performed at various temperatures ranging from $30^{\circ} \mathrm{C}, 35^{\circ} \mathrm{C}$, and $40^{\circ} \mathrm{C} . \mathrm{pH}$ optimum was analyzed by measuring the activity remaining after incubation using different buffer with $\mathrm{pH}$ 4-7.

\section{F. Lignin Determination and Cellulose Determination}

Lignin (\%) and cellulose (\%) were calculated from ADF Method, for the gravimetric method of lignin and cellulase determination [2] ,[7], [13].

\section{RESULTS AND DISCUSSION}

\section{A. Identification of Strain}

The 18S rRNA gene sequence from fungus was determined and based on BLAST sequence comparison, confirmed that the isolated strain apw-tt2 was Penicillium sp.

The result of the analysis shows that the Penicillium is a new species that has the closest genetic relation with Penicillium decumbens and Penicillium expansum (Fig.1), with the highest percent identitif against Penicillium expansum $99.6 \%$ and $99.3 \%$ against Penicillium decumbens., with $99 \%$ homology.

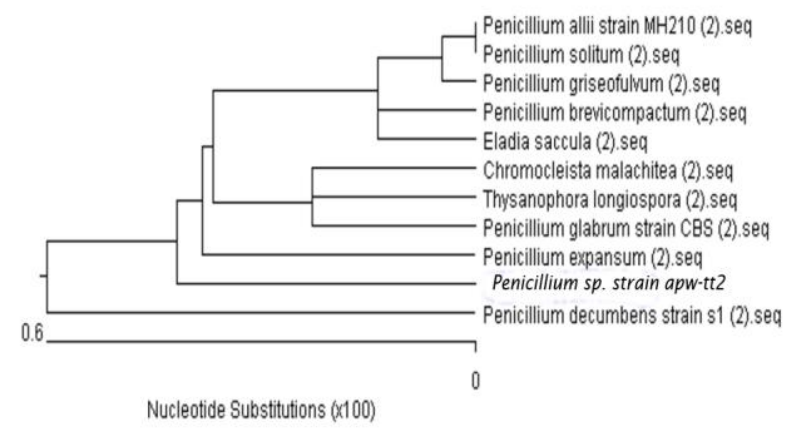

Fig. 1. Phylogenetic tree based on 1165-bp of the gene 18s for Penicillium strain sp. apw-tt2 determined using Clustal Method based on alligment of 1165-bp 18s rRNA.

\section{B. Production of Ligninase and Growth of Fungi}

Fig. 2 show that biomass increased markedly during the first 4 days and then showed a declining trend during the biodelignification. In Fig. 3 the ligninase activity peaked at Day 4. The results indicated there is a pattern alignment enzyme production of ligninase and cell growth of Penicilium sp. strain apw-tt2.

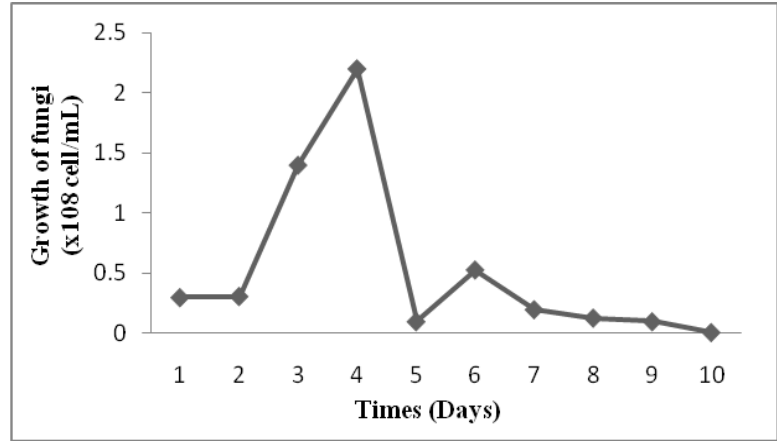

Fig. 2. Growth of Penicillium sp. strain apw-tt2 during delignification of rice straw in conditions $\mathrm{pH} 5,30^{\circ} \mathrm{C}$

C. Dependence of Enzyme Activity on Temperature and pH Optimum

The effect of $\mathrm{pH}$ on the ligninase activity are shown in Fig.4. Determination profile $\mathrm{pH}$ by measuring the enzyme activity at various $\mathrm{pH}$ from 4 - 7. The maximum ligninase activity was observed at $\mathrm{pH}$, increasing $\mathrm{pH}$ for condition of incubation showed reducing of the activity of the enzyme.

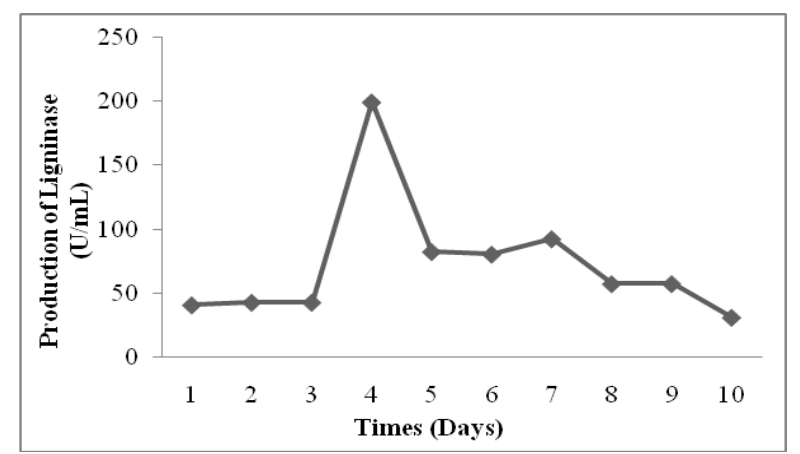

Fig. 3. Production of ligninase during biodelignification of rice straw using Penicillium sp. strain apw-tt 2 in conditions $p H 5,30^{\circ} \mathrm{C}$

The optimum temperature for maximum ligninase production by Penicilium sp. strain apw-tt2 was found to be $35^{\circ} \mathrm{C}$ on Day 4 with an activity of $571 \mathrm{U} / \mathrm{ml}$. Given that the enzymatic reaction will be increased with higher temperatur, indicated that in this case the stability of ligninase remained at 
$40{ }^{\circ} \mathrm{C}$, therefore the addition of temperatures above $40^{\circ} \mathrm{C}$ may still determinate.

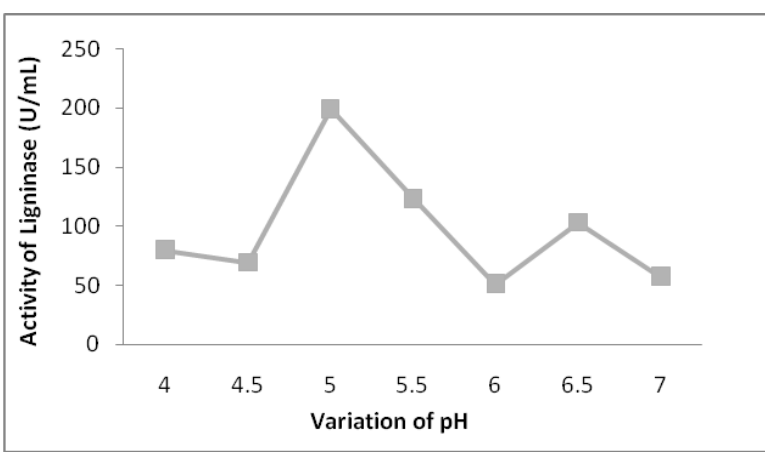

Fig. 4. Lignolitic enzyme activity in Penicillium sp. strain apw-tt2 under variation of $\mathrm{pH}$ at $30^{\circ} \mathrm{C}$

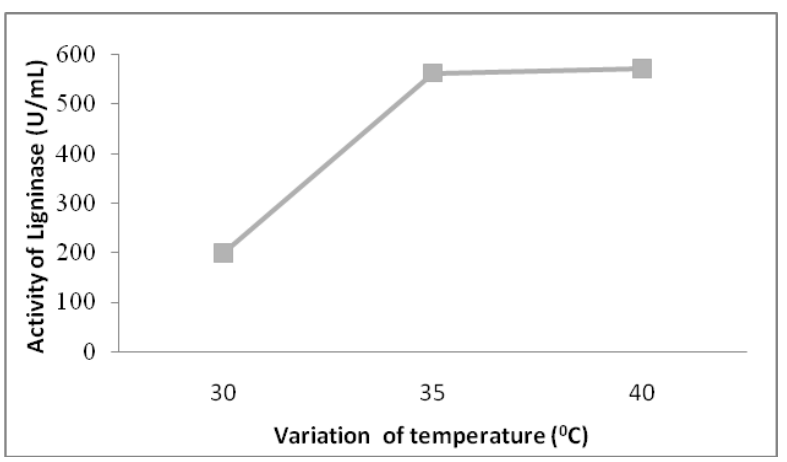

Fig. 5. Lignolytic enzyme activity in Penicillium ap strain apw-tt2 under different temperature condition at $\mathrm{pH} 5$

\section{Analysis of Pulp}

Delignification selectivity can be determined from the comparison of the degradation of lignin and cellulose during the process of delignification. Biodelignification of rice straw for four days by Penicillium sp. strain apw-tt2 resulted in decreased levels of $66.3 \%$ lignin, cellulose degradation was detected only $28 \%$.

\section{E. Analysis Scanning Electron Microscope (SEM)}

SEM confirmed that penetration of fungal mycelium on straw and analyzed the changes in lignin degradation. Structural fibers were observed at $200 \mathrm{x}$ magnification (Fig. 6.) and the control (straw without fungus) which may indicated that the structure of the cell wall are still visible piled and rich of the lignin
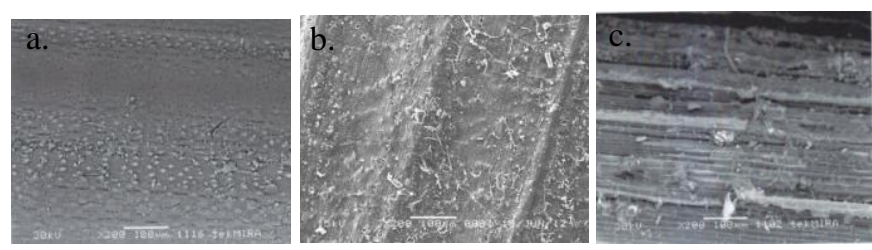

Fig. 6. Photomicrograph SEM (a): Control (straw without fungus); (b) delignification 4 days; (c) delignification 10 days.

While the straw that had been treated for 4 days by the fungus suggests that the cell wall has been degraded and the fibers begin to appear on the cell surface that is dominated by the growth of mycelium. To show the fungal activity on straw delignification for 10 days, lignin degraded on the cell structure of the straw which lignin component dwindling and the growing mold spores have penetrated into the interior of the cell wall.

\section{DISCUSSION}

The results of this study indicate that the Penicillium sp. strain apw-tt2. is an indigenous fungus from rice straw showed potencial to become ligninase producer. Initial study indicated there was high activity of ligninase that qualitatively proven by clear zone test (data not shown). Quantitatively, by assay ligninase during the incubation process showed there was consistency in the ability to produce high ligninase.

The novelty of this study is when the results of DNA sequencing of Penicillium sp. strain apw-tt 2 and according to the phylogenetic tree dendogram showed that an isolate from rice straw is a new species that have DNA character which located between Penicillium decumbens and Penicillium expansum.

Some studies biopulping include the Penicillium sp. KSt3 produce ligninase activity $3.32 \mathrm{U} / \mathrm{mL}$ [14]. Incubation using immobilized polyurethane foam, the production of lignin-degrading enzyme Lignin (Lip), manganese peroxidase (MNP), and laccase (Lac) by the white-rot fungus Bjerkandera adusta showed the maximum activity of the enzymes were 450, 370, $100 \mathrm{U} / \mathrm{ml}$ [10]. Pycnoporus coccineus showed that levels of lignin can be degraded as much as $26.9 \%$, and the enzyme lignolytic activity detected $23 \mathrm{U} / \mathrm{mL}$ within 60 days [15]. In this study, at the optimum conditions Penicillium strain apw-tt2 the lignin was degraded $66.3 \%$ and reduction of cellulose that was detected only $28 \%$. Pulping process would be good if only slight damage the cellulose in the straw, but the dissolution of lignin in high level [16], therefore the use of Penicillium strain apw-tt2 can be designed in process biopulping to produce good quality paper.

\section{ACKNOWLEGMENTS}

A part of this work was supported by the Ministry of Education National Indonesia.

\section{REFERENCES}

[1] M. Asther, C. Cecile, and C. Georges, "Control of lignin peroxidase production by Phanerochaete chrysosporium INA-12 by temperature shifting," Appl. and Env. Microbiol, pp. 3194-3196, vol. 54, no.12, 1988.

[2] A. M. Bonnen, L. H. Anton, A. B. Orth, "Lignin - degrading enzymes of the commercial button mushroom, Agaricus bisporus," Appl. Environ. Microbiol, vol. 60, pp. 960-965, 1994.

[3] I. Eichlerová, R. Katia, L. Homolka, P. J. Jean, and N. František, "Ligninolytic characteristics of Pleurotus ostreatus strain F6 and its monokaryotic protoplast derivative P19," Can. J. Microbiol, vol. 46, pp. 1153-1158, 2000, Canada, 2000.

[4] Y. Nakamura, G. S. Mtui, S. Tatsuro, and K. Masaaki, "Lignin degrading enzyme production by Bjerkandera adusta immobilized on Polyurethane Foam," J. of Bioscience and Bioengineering, vol. 88 no. 1, pp. 41-47, 1999.

[5] K. P. Narkhede and N. N. Vidhale, "Biopulping studies using an effluent isolate Curvularia lunata LW6," J. Biotech. vol. 5, pp. 385-388, 2005.

[6] M. A. Belewu, "Conversion of masonia tree sawdust and cotton plant by product into feed by white rot fungus (Pleorotus sajor caju),"African Journal of Biotech vol. 5, pp. 503 - 504. 2006.

[7] F. Patrick, M. Godliving, M. M. Anthony, and Amelia, "Optimization of laccase and manganese peroxidise production in submerged culture of Pleurotus sajor-caju," African Journal of Biotechnology, vol. 10, no. 50, pp. 10166-10177, 2011. 
[8] Y. S. Yang, J. T. Zhou, H. Lu, Y. L. Yuan, and L. H. Zhao, "Isolation and characterization of a fungus Aspergillus sp. strain F-3 capable of degrading alkali lignin," Journal Springer, 2011.

[9] Z. Zheng, R. E. Levin, J. L. Pinkham, and K. Shetty, "Decolorization of polymeric dyes by a novel Penicillium isolate,"Process Biochemistry, vol. 34, pp. 31-37, 1999.

[10] S. M. Hossain and N. Anantharaman, "Effect of wheat straw powder on enhancement of ligninolytic enzyme activity using P.chrysosporium," J of Biotech. vol. 7, pp 502-507, 2008.

[11] C. Y. Liew, A. Husaini, H. Hussain, S. Muid, K. C. Liew, and H. A. Rosian, "Lignin biodegradation and ligninolytic enzyme studies during biopulping of Acacia mangium wood chips by tropical white rot fungi," World J Microbiol Biotechnol, vol. 27, pp. 1457-1468, 2011.

[12] O. Sánchez, R. Sierra1, and C. J. Alméciga-Díaz, "Delignification process of agro-industrial wastes an alternative to obtain fermentable carbohydrates for producing fuel," Bogotá Colombia, 2011.

[13] P. J. Van Soest and R. H. Wine, "Determination of lignin and cellulose in acid-detergent fiber with permanganate," J. Assoc Off Anal Chem., vol. 51, pp. 780-785, 1968

[14] Y. B. Subowo and D. Corazon, "Seleksi jamur tanah pengurai lignin dan PAH dari beberapa lingkungan di Bali," Berita Biologi, vol. 10, no. $2,2010$.

[15] P. Singh, O. Sulaiman, R. Hashim, P. F. Rupani, and L. C. Peng, "Biopulping of lignocellulosic material using fungal species: A review," Rev. Environ Sci. Biotechnol., vol. 9, pp. 141-151, 2010.

[16] F. D. dan G. Wegener, Kayu; Kimia, Ultrastruktur dan Reaksi-Reaksi, Yogjakarta : Gajah Mada University Press, Wood, Chemistry, Ultrastructure, Reactions, 1995.

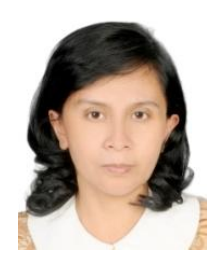

Asri Peni Wulandari was born in Bandung, Indonesia on 13rd August 1965. Currently, she is associated with Universitas Padjadjaran, Indonesia, as Assistant Professor in the Department of Biology. She has obtained her Bachelor of Science in Biology Department from Bandung Institute of Technology , Indonesia , in 1989; her Master's in Tokyo Institute of Technology, Japan in 1998. Her Ph.D program achieved from The University of Tokyo, Japan, in 2003. Her achievment include : Award of the Agricultural Chemistry Scholarship, in light of the outstanding results of study and research in Dept. of Applied Biological Chemistry/Biotechnology. The Foundation of Dept. of Agricultural Chemistry, The University of Tokyo, 2001 and The Best Poster Presentation on The First Symposium on Carbohydrate Enzyme Bioengineering, held by Institute of Technologi Bandung-Koninklijke Nederlamdse Akademie van Wetenschappen, Rijksuniversiteit Groningen Padjajaran University. 2005 She has authored ten publications for journal international and national. She is member of many profesional bodies including Micoina, ABI. She is currently pursuing her research in the biocatalyst production for biodegradation of biomass. Currently focused researcehed on the field of natural fiber. Her other interest include renewable bioenergy from microalgae.

Tika Triyana was born in Bandung, Indonesia on $28^{\text {th }}$ July 1989. Graduated from Department of Biology, Universitas Padjadjaran,in 2012. Her achievements include scholarship to studied in Padjadjaran University from Eka Tjipta foundation, $1^{\text {st }}$ winner poster scientific in the field of energy, and $2^{\text {nd }}$ winner presentation in the science week national student.

Poniah Andayaningsih was born on $5^{\text {th }}$ April 1943. She is Professor of the Department Biology, Padjadjaran University. She has worked as a supervisor for research mainly of fungi. 